\title{
SPRED proteins and their roles in signal transduction, development, and malignancy
}

\author{
Claire Lorenzo and Frank McCormick \\ Helen Diller Family Comprehensive Cancer, University of California at San Francisco, San Francisco, California 94158, USA
}

The roles of SPRED proteins in signaling, development, and cancer are becoming increasingly recognized. SPRED proteins comprise an $\mathrm{N}$-terminal EVH-1 domain, a central c-Kit-binding domain, and C-terminal SROUTY domain. They negatively regulate signaling from tyrosine kinases to the Ras-MAPK pathway. SPRED1 binds directly to both c-KIT and to the RasGAP, neurofibromin, whose function is completely dependent on this interaction. Loss-of-function mutations in SPRED1 occur in human cancers and cause the developmental disorder, Legius syndrome. Genetic ablation of SPRED genes in mice leads to behavioral problems, dwarfism, and multiple other phenotypes including increased risk of leukemia. In this review, we summarize and discuss biochemical, structural, and biological functions of these proteins including their roles in normal cell growth and differentiation and in human disease.

Ras proteins are binary molecular switches that cycle between GTP-bound on and GDP-bound off states. Accumulation of active Ras-GTP in response to growth factors is understood in some detail where the translocation of guanine exchange factor (GEF), such as SOS, to the plasma membrane stimulates the nucleotide exchange on Ras from GDP to GTP (Buday and Downward 1993). GTPbound Ras proteins activate the MAPK kinase cascade by binding and recruiting Raf to the membrane (Terrell et al. 2019). This cascade regulates a variety of biological processes such as cell proliferation, differentiation, and survival. Ras proteins also bind activate PI 3' kinases, RalGDS proteins, and possibly other effector pathways (Simanshu et al. 2017). Conversion of Ras-GTP back to the inactive form, and maintenance of Ras in the inactive form prior to restimulation is mediated by GTPase-activating proteins (GAPs), such as neurofibromin and RASA (p120 RasGAP).

[Keywords: Legius syndrome; NF1; Ras-MAPK; SPROUTY; signal transduction]

Corresponding author: frank.mccormick@ucsf.edu

Article is online at http://www.genesdev.org/cgi/doi/10.1101/gad.341222. 120 .
Ras signaling is tightly controlled; hyperactive Ras signaling results in diseases such as cancer, developmental disorders (known collectively as RASopathies) and learning disabilities (Simanshu et al. 2017). To maintain tight control of Ras activity, numerous signals and interactions regulate the duration, magnitude and context of Ras activation. SPRED proteins, and their better-known relatives, proteins of the Sprouty family, are negative regulators of Ras signaling. Although SPRED and Sprouty proteins share a conserved C-terminal Sprouty (SPR) domain, the mechanisms by which they regulate Ras signaling are distinct.

The SPROUTY gene was first identified as a negative regulator of FGF signaling and tracheal branching in Drosophila (Hacohen et al. 1998). The role of Sprouty proteins as negative regulators of Ras-MAPK signaling is conserved from Drosophila to humans (Hacohen et al. 1998; Casci et al. 1999). Sprouty proteins inhibit Ras activation by preventing the membrane localization of SOS, a Ras GEF, by binding and sequestering GRB2, an adaptor protein that links the phosphorylated receptor tyrosine kinase (RTK) with SOS (Fig. 1). Activated RTKs, such as FGFR, EGFR, and VEGFR, phosphorylate a conserved phosphotyrosine in Sprouty, which is recognized by the $\mathrm{SH} 2$ domain found on GRB2 and competes for GRB2 binding with SOS (Hanafusa et al. 2002). Sprouty proteins are down-regulated by dephosphorylation of the phosphotyrosine by the phosphatase Shp2 (Hanafusa et al. 2004) or engagement with c-Cbl, an E3 ubiquitin-ligase, which results in polyubiquitination and proteasomal degradation (Hall et al. 2003; Mason et al. 2004). In addition to GRB2 binding, Sprouty may also regulate Ras signaling by binding Raf, which inhibits Raf kinase activity (Fig. 1; Yusoff et al. 2002).

Sprouty-related SPRED proteins were identified in a yeast two-hybrid screen to identify proteins that interact with RTKs c-Kit and c-Fms (Wakioka et al. 2001). This screen identified SPRED1 as a binding partner for the intracellular kinase domain of c-Kit in its inactive state.

(C) 2020 Lorenzo and McCormick This article is distributed exclusively by Cold Spring Harbor Laboratory Press for the first six months after the full-issue publication date (see http://genesdev.cshlp.org/site/misc/ terms.xhtml). After six months, it is available under a Creative Commons License (Attribution-NonCommercial 4.0 International), as described at http://creativecommons.org/licenses/by-nc/4.0/. 


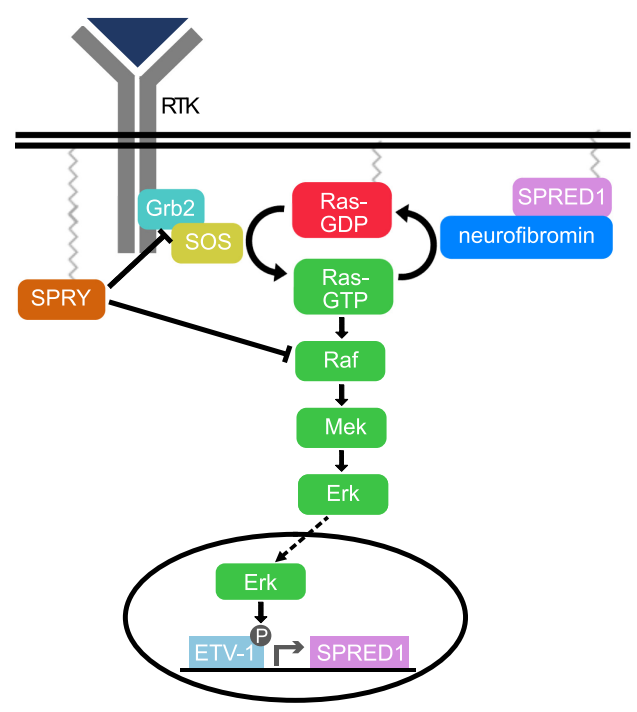

Figure 1. Inhibitory mechanism of Spred and Sprouty proteins on the Ras-MAPK pathway. SPRED proteins down-regulate Ras signaling by recruiting RasGAP, neurofibromin to the membrane. SPRED loss primarily activates Ras-MAPK signaling though Ras activates other pathways such as PI3K, PLC- $\varepsilon$, and RAL-GDS. Sprouty proteins down-regulate Ras signaling by sequestering Grb2 and preventing the membrane recruitment of RasGEF, SOS, and by inhibiting Raf kinase activity.

SPRED2 was identified through searching genomic databases, in the same study, due to its high sequence similarity to SPRED1. Similarly, the same group identified $S P R E D 3$, a few years later (Kato et al. 2003). Like Sprouty, SPRED proteins inhibit growth factor-mediated activation of Ras-MAPK signaling. However, SPRED proteins function through regulation of Ras GAPs rather than Ras GEFs. SPRED1 cooperates with neurofibromin, a Ras GAP, and is essential for neurofibromin function (Stowe et al. 2012; Dunzendorfer-Matt et al. 2016; Hirata et al. 2016). Consistent with this, heterozygous germline loss of function of SPRED1 results in Legius syndrome (LS), which shares a similar phenotype with neurofibromatosis type 1 (NF1), a syndrome caused by loss-of-function mutations in neurofibromin (Brems et al. 2007). Other reports suggest that SPRED suppresses Ras signaling by preventing the phosphorylation and activation of Raf (Wakioka et al. 2001; Nonami et al. 2005). However, both mechanisms have not been fully characterized.

\section{SPRED isoforms}

SPRED1, SPRED2, and SPRED3 share similar overall structure (Fig. 2A). Their chromosomal localization is summarized in Table 1. Human SPRED1 gene spans 444 amino acids, while SPRED2 spans 418 residues with $55 \%$ sequence identity. SPRED 3 spans 410 residues and shares $38 \%$ sequence identity to SPRED1. While both SPRED1 and SPRED2 effectively suppressed growth factor-mediated Erk activation, SPRED3 possessed less inhibitory activity (Kato et al. 2003). This suggests that each member of the SPRED family may have a selective capacity and function for the regulation of Ras-MAPK signaling.

\section{Protein structure}

\section{EVH-1 domain}

The N-terminal region of SPRED family members is comprised of an enabled/VASP homology-1 (EVH-1) domain (Fig. 2A), one of the four distinct interaction domains among SH3-WW, GYF, and EVH-1-that recognize proline-rich sequences (Peterson and Volkman 2014). The EVH-1 domain has been found in $~ 630$ human proteins (Peterson and Volkman 2014). This domain spans 115 residues in length and is invariably located at the $\mathrm{N}$ terminus. EVH-1 domains are found in multidomain scaffolding proteins that mediate multiprotein complex assembly associated with modulating the actin cytoskeleton or signal transduction in postsynaptic compartments (Ball et al. 2002) Despite having low sequence homology, EVH-1

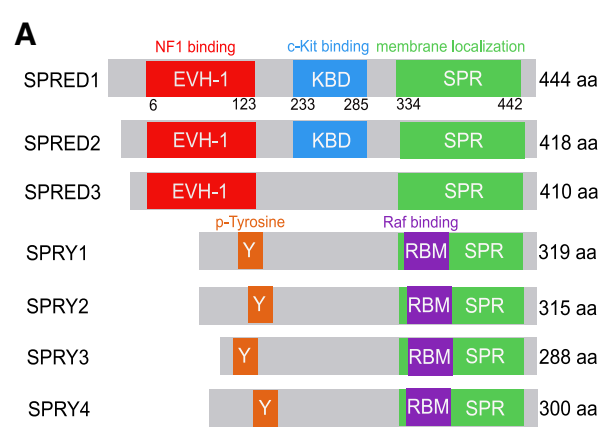

\section{B}

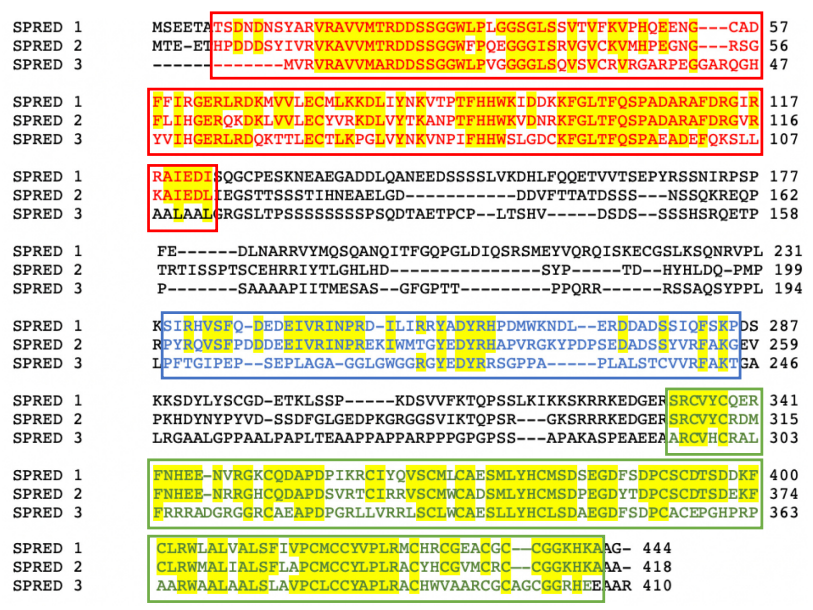

Figure 2. Domain and sequence alignments of human SPRED and Sprouty proteins. (A) Domain structure of SPRED and Sprouty proteins. SPRED proteins share a N-terminal EVH-1 domain and C-terminal sprouty domain. SPRED1 and SPRED2 share a central c-Kit-binding domain. Sprouty proteins share a conserved tyrosine and C-terminal sprouty domain. (B) Sequence alignment of SPRED proteins. (Red) EVH-1 domain, (blue) KBD, (green) SPR, (highlighted in yellow) conserved residues. 
Table 1. Chromosomal localization

\begin{tabular}{lcl}
\hline & Human & \multicolumn{1}{c}{ Mouse } \\
\hline SPRED1 & $15 \mathrm{q} 13.2$ & $2 \mathrm{E} 5$ \\
SPRED2 & $2 \mathrm{p} 14$ & $11 \mathrm{~A} 3-\mathrm{A} 4$ \\
SPRED3 & $19 \mathrm{q} 13.13$ & $7 \mathrm{~A} 3$ \\
\hline
\end{tabular}

Chromosomal localization was identified by an NCBI database search for "human" and Kato et al. 2003 for "mouse."

domains consist of two perpendicular antiparallel $\beta$-sheets followed by a C-terminal $\alpha$-helix (Peterson and Volkman 2014). Structural studies with the SPRED1 EVH-1 domain from Xenopus tropicalis found that the polyproline-binding groove is narrower than in other EVH-1 domains (Harmer et al. 2005). The only known interactor for SPRED EVH-1 is neurofibromin, which does not contain proline-rich sequences within the interaction region (Harmer et al. 2005; Stowe et al. 2012). Together, this demonstrates a new binding mechanism for SPRED EVH-1 that does not require proline-rich sequences similar to other EVH-1 interactors (Hirata et al. 2016), and presents a new mode of protein-protein interaction that may exist in other proteins containing an EVH-1 domain. Finally, although the three SPRED proteins bind neurofibromin, the SPRED3 EVH-1 has a much weaker binding affinity compared with SPRED1 and SPRED2 (Hirata et al. 2016). Unlike SPRED1 and SPRED2, sequence alignment of SPRED proteins shows that SPRED3 has a smaller $\mathrm{N}$ terminus and contains a three-amino-acid insertion in the $\beta 4$ strand (Yan et al. 2020); this corresponds to decreased sequence identity between SPRED1 and SPRED3 $(57 \%)$, compared with SPRED2 (67\%). These differences in amino acid sequence likely cause minor changes in tertiary structure of SPRED3 EVH-1 domain and may be responsible for weaker neurofibromin binding and ERK suppression activity of SPRED3. Indeed, several residues in SPRED1 (L32, T86, and T88), which directly interact with neurofibromin via nonbonded contacts and hydrogen bond are not conserved in SPRED3 (Yan et al. 2020).

\section{KBD domain}

The central region of SPRED contains the c-Kit-binding domain (KBD) (Fig. 2A). This domain spans 50 residues and was initially identified through a yeast two-hybrid screen for tyrosine kinase-binding proteins (Wakioka et al. 2001). This interaction domain is unrelated to any previously identified tyrosine kinase interaction domains such as SH2 and PTB domain (Wakioka et al. 2001). Although SPRED2 KBD only shares $51 \%$ identity with SPRED1 $\mathrm{KBD}$, SPRED2 also binds to c-Kit via this region. In contrast, the corresponding domain of SPRED3 shares $<20 \%$ identity with SPRED1 KBD (Fig. 2A). Arginine 247 of SPRED1 is required for c-Kit binding (Kato et al. 2003), but in SPRED3 the equivalent residue (240) is a glycine. As a result, SPRED3 does not bind or become phosphorylated by c-Kit, unlike SPRED1 and SPRED2 (Kato et al. 2003). Moreover, it is not known whether SPRED proteins can also interact with other RTKs besides c-Kit; perhaps the KBD is a new in- teraction domain that mediates binding with RTKs, allowing RTKs to regulate SPRED function.

\section{SPR domain}

The C-terminal region of SPRED proteins consists of the Sprouty (SPR) domain (Fig. 2A), a conserved cysteine-rich domain analogous to that found in Sprouty proteins (Fig. 2C). Despite attenuation of Ras signaling by apparently distinct mechanisms, membrane localization is consistently important for efficient inhibition by both SPRED and Sprouty. Sprouty proteins translocate to membrane raft/caveolae following growth factor stimulation (Impagnatiello et al. 2001; Lim et al. 2002). Caveolae represent a subset of lipid rafts that are implicated in signal transduction-related events due to the presence of signaling proteins such as RTKs (Bastiani and Parton 2010). Membrane localization of Sprouty proteins may be a consequence of their interaction with a membrane-associated scaffold protein, caveolin-1, and/or through palmitoylation (Impagnatiello et al. 2001). Similar to Sprouty, SPRED proteins localize in lipid rafts/caveolae where they interact with caveolin-1 (Nonami et al. 2005). SPRED1 and SPRED3 also interact with a palmitoyl acetyltransferase, HIP14, and coexpression leads to palmitoylation of SPRED (Butland et al. 2014). Additionally, SPRED1 associates with B-Raf in the cytoplasm, where B-Raf/C-Raf dimerization induces SPRED1 membrane translocation to the plasma membrane (Siljamäki and Abankwa 2016). The SPR domain of SPRED is important for effective Ras inhibition by translocating neurofibromin to the plasma membrane where it can interact with Ras (Stowe et al. 2012). SPRED mutants with deletion of the SPR domain fail to localize to the plasma membrane and fail to inhibit ERK phosphorylation (King et al. 2005). Moreover, pathogenic SPR mutations in SPRED1 bind neurofibromin but fail to recruit it to the plasma membrane (Stowe et al. 2012; Hirata et al. 2016). Altogether, these data show that the SPR domain is necessary to down-regulate Ras signaling by recruiting neurofibromin to the plasma membrane compartment in which it can interact with Ras. RASA1/p120RasGap does not interact with SPRED proteins, as discussed below. This GAP is recruited to the plasma membrane through interactions between its $\mathrm{SH} 2$ domains and phospho-tyrosines on activated RTKs, such as PDGFR and EphA2 (Tong et al. 2003). The mechanisms by which other GAPs are recruited to Ras in the plasma membrane remain to be determined.

In addition to membrane localization, the SPR domain plays a role in SPRED and Sprouty dimerization (Hanafusa et al. 2002; King et al. 2005). SPRED1, SPRED2, and SPRED3 have been found to heterodimerize, although SPR deletion mutants cannot (King et al. 2005). However, the affinity, context, and consequences of dimerization are unclear. Furthermore, membrane localization and Ras inhibition in $\triangle$ SPR mutants were rescued by the addition of CAAX motif (Stowe et al. 2012), a consensus sequence known to undergo a series of post-translational modifications that allow proteins to associate with membranes (Wright and Philips 2006). It was previously shown that 
the CAAX motif induces Ras dimerization (Nan et al. 2015). Interestingly, neurofibromin was recently identified as a high-affinity dimer in cells (Sherekar et al. 2020) and suggests that these signaling complexes are regulated by dimerization, although the precise mechanisms remain to be elucidated.

\section{Protein interactions}

\section{Neurofibromin}

Neurofibromin interacts with SPRED through the EVH-1 domain (Stowe et al. 2012). Neurofibromin negatively regulates Ras signaling through its function as a GAP to accelerate the hydrolysis of GTP (Martin et al. 1990; Xu et al. 1990). This interaction is necessary for the recruitment of neurofibromin to the plasma membrane where it can down-regulate Ras activity (Stowe et al. 2012) and provides a satisfying explanation for the phenotypic overlap between loss of SPRED1 function in Legius syndrome and loss of function of neurofibromin in NF1, discussed later.

The crystal structure of the neurofibromin GAP-related domain (GRD) (PDB:6V65) consists of a module of two subdomains: the central domain (GAPc), which is necessary and sufficient to bind and inactivate Ras, and the extra domain (GAPex), which is composed of the N-terminal and C-terminal residues flanking the central GAP domain (Fig. 3B; Yan et al. 2020). The neurofibromin-GAPc primarily interacts with RAS. Meanwhile, the neurofibromin-GAPex region forms two crossing a-helix coils at one end outside the GAPc region, and is required for binding to the SPRED1 EVH-1 domain (Fig. 3A,B; Dunzendorfer-Matt et al. 2016). Although the GAPex region has been shown to be dispensable for GAP activity in vitro (Hirata et al. 2016), the GAPex region is the major interaction domain for SPRED1 binding (Dunzendorfer-Matt et al. 2016; Sherekar et al. 2020). The N-terminal residues of neurofibromin GAPex forms a salt bridge and hydrogen bonds with residues in SPRED1 EVH-1 domain. Meanwhile, the C-terminal residues of neurofibromin GAPex have a less direct interaction with SPRED1 and instead act as structure-supporting module to maintain the overall architecture of neurofibromin GAPc and GAPex domains through hydrophobic interactions and a weak hydrogen bond. Besides the GAPex, the GAPc region also interacts with SPRED1 EVH-1 and contributes to complex stabilization mainly through hydrophobic interaction (Yan et al. 2020). Furthermore, the SPRED1 region forming the neurofibromin-SPRED1 interphase in the crystal structure was found to be highly flexible in NMR studies (Führer et al. 2017). LS mutations such as R24Q (Sumner et al. 2011), G30R (Sumner et al. 2011), and T102R (Messiaen et al. 2009) disrupt electrostatic interactions with neurofibromin, and result in decreased or undetectable binding (Führer et al. 2017; Fig. 3A,B; Yan et al. 2020). Likewise, several NF1 patient mutations that map to the GAPex region resulted in reduced binding with SPRED1 EVH-1 domain (Fig. 3D; Hirata et al. 2016). These LS and NF1 mutations are located at the neurofibromin-SPRED1 interface and form direct interac- tions between neurofibromin and SPRED1 (Fig. 3E; Yan et al. 2020).

$c-K i t$

Both SPRED1 and SPRED2 bind c-Kit and are phosphorylated on tyrosine residues in response to growth factor stimulation with SCF, PDGF, and EGF. The binding site for c-Kit was mapped to a 50-amino-acid region (codon 233-285) in SPRED1 subsequently designated the "cKit-binding domain" (Wakioka et al. 2001). Despite this, little is known about the consequence and context of cKit binding to SPRED, perhaps interaction with c-Kit contributes to SPRED membrane localization and allows growth factor-dependent regulation of SPRED membrane translocation.

\section{Protein expression pattern}

The mild phenotypes of both SPRED1 and SPRED2 knockout mice (discussed below) suggest some redundancy between the two proteins. RNA expression profiling shows that SPRED1 and SPRED2 have overlapping expressions and are both widely expressed across human tissues (Fig. 4A; The Genotype Tissue Expression Project, https:// www.gtexportal.org/home). Protein expression profiling through immunohistochemistry staining of various human tissue sections shows similar expression distribution (Fig. 4B; The Human Protein Atlas, https://www .proteinatlas.org). In contrast, RNA expression profiling shows that, unlike SPRED1 and SPRED2, SPRED3 expression is limited to the brain, pituitary gland, and breast (Fig. 4A; The Genotype Expression Project, https://www .gtexportal.org/home; Kato et al. 2003).

In addition, expression patterns of SPRED proteins change during development. Comparing protein levels in fetal and adult mouse tissue lysates, SPRED1 is expressed in fetal liver, brain, and heart, whereas SPRED2 is not detected in these fetal tissues (Engelhardt et al. 2004). This suggests that SPRED1 may be more functionally important during fetal development. This is in agreement with the observations that germline mutations in SPRED1 result in the developmental disorder Legius syndrome (LS) as discussed below, whereas mutations in SPRED2 have never been reported in this disease.

\section{Transcriptional regulation}

Ras signaling pathways control gene expression through phosphorylation and regulation of transcription factors, coregulatory proteins, and chromatin proteins (Whitmarsh 2007). Levels of Ras-MAPK activation are tightly controlled by ERK-regulated transcriptional regulation of negative feedback regulators (Pratilas et al. 2009; Dry et al. 2010). For example, SPROUTY1, SPROUTY2, and $S P R O U T Y 4$ expression is known to be positively regulated by ERK signaling resulting from RTK activation (Ozaki et al. 2001; Packer et al. 2009). Recently, SPRED1 and SPRED2 expression has been shown to be positively 
A

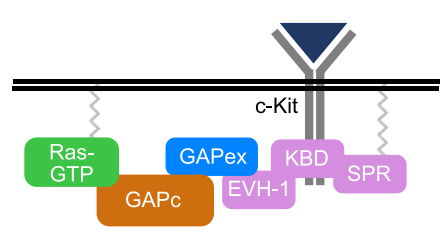

C

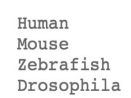

Zebrafish Drosophila (1)
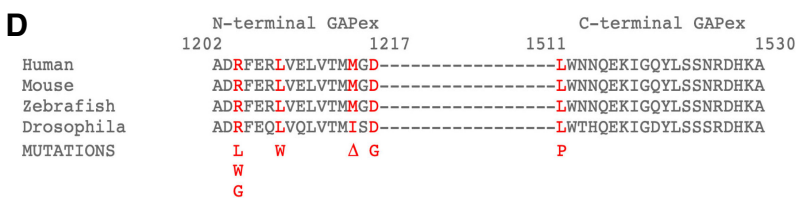

$\mathbf{E}$

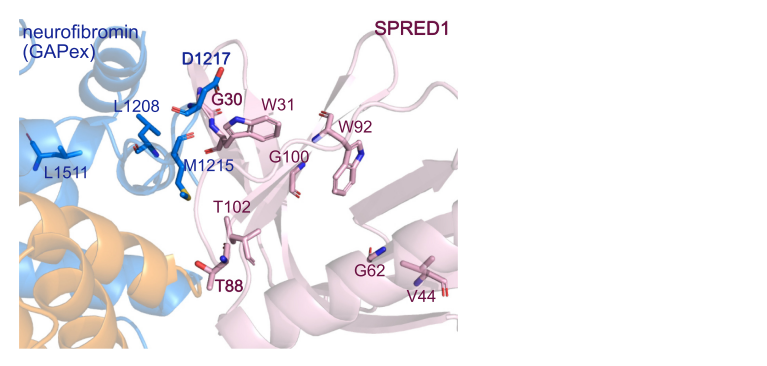

B

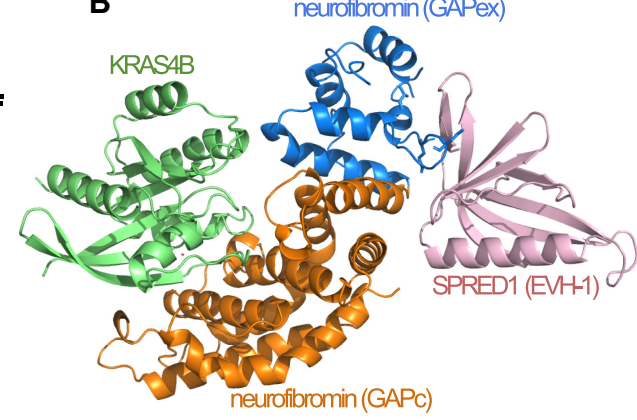
27 SSGGWLPLGGSGLSSVTVFKVPHQE--ENGCADFFIRGERLRDKMVVLECMLKKDLIYNKVTPTFHHWKIDDKKFGLTFQ SSGGWLPLGGSGLSSVTVFRVPHQE--ENGCADFF IRGERLRDKMVVLECMLKKDLI YNKVTPTFHHWKIDDKKFGLTFQ

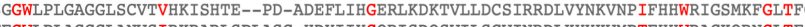

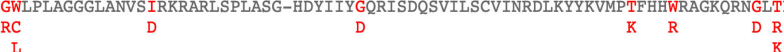

$\mathrm{R}$
$\mathrm{K}$
Figure 3. Model for neurofibromin membrane recruitment through SPRED1 interaction. (A) SPRED1 EVH-1 domain directly binds to the GAPex domain of neurofibromin GRD. SPRED1 KBD interacts with c-Kit. SPRED1 SPR is membrane anchored through palmitoylation. Neurofibromin GAPc interacts with Ras. $(B)$ Overall structure of the complex formed by GMPPNP-bound KRAS (green), neurofibromin GRD (blue), and SPRED1 EVH1 (pink) (PDB:6V65). (C) Ortholog alignment of SPRED EVH domain with LS mutations that disrupt SPRED1-neurofibromin binding in red. $(D)$ Ortholog alignment of neurofibromin GAPex with NF1 mutations that disrupt SPRED1-neurofibromin binding in red. $(E)$ Mapping of pathogenic mutations in SPRED1 (pink) and NF1 (green) on the neurofibrominSPRED1 complex (PDB:6V65). regulated by Ras-MAPK signaling in melanoma and GIST cell lines (Xie et al. 2018). Pharmacological inhibition of the Ras pathway, either with MEK, c-Kit, or RAF inhibitors, resulted in decreased SPRED expression $6 \mathrm{~h}$ after treatment and remained down-regulated at $24 \mathrm{~h}$ (Packer et al. 2009; Pratilas et al. 2009; Xie et al. 2018). In these cells, SPRED expression is regulated by ETV1, a member of the Ets family of transcription factors. ETV1 is overexpressed in melanoma (Jané-Valbuena et al. 2010) and gastrointestinal stromal tumors (Ran et al. 2015). ETV1 transcription activity is stimulated by Ras-MAPK activation where Erk1-mediated phosphorylation regulated ETV1 protein stability (Janknecht 1996; Bosc et al. 2001; Oh et al. 2013). Finally, sequencing of tumor tissues and cancer cell lines demonstrated a correlation between BRAF V600E or KRAS G12 mutations with high SPRED1 mRNA expression (Cerami et al. 2012; Figshare, https:// figshare.com/articles/dataset/DepMap_20Q2_Public/122 80541).

\section{Genetic models}

\section{Mouse models}

SPRED $1^{-/-}$mice were generated by deleting exons encoding for KBD and SPR domains. These mice were generally healthy and fertile despite having lower body weight and a shortened face (Inoue et al. 2005). Mice exhibited increased pigmentation in ears, paw pads, and tails (Tadokoro et al. 2018). Mice lacking SPRED1 demonstrated cognitive impairments in hippocampus-dependent visuo-spatial memory (Denayer et al. 2008). SPRED1-/mice displayed learning deficits in the Morris water maze and T-maze tests (Denayer et al. 2008). In cognitively more demanding stages of the T-maze, SPRED $1^{+/}$mice performed at an intermediate level between wild-type and SPRED1 ${ }^{-/-}$littermates (Denayer et al. 2008). The cognitive and synaptic plasticity phenotype in SPRED1-/mice were remarkedly similar to $N F 1^{+/-}$mice, where treatment with statins, which interfere with Ras membrane anchoring and activation, acutely rescued the learning and synaptic plasticity defects (Cui et al. 2008). Similarly, learning difficulties have been reported in Legius syndrome (Brems et al. 2007; Pasmant et al. 2009) and NF1 patients (Costa et al. 2002; Hyman et al. 2005), where deficits visuo-spatial and visual constructive skills are considered hallmarks of NF1. SPRED1 $1^{-/-}$mice also exhibited allergen-induced airway eosinophilia indicating that SPRED1 may negatively regulate IL-5-mediated eosinophil proliferation, possibly by inhibiting Ras-MAPK signaling (Inoue et al. 2005).

SPRED $2^{-/-}$mice were generated using a gene trap inserted between exons 4 and 5 of SPRED2. These mice appeared healthy and fertile despite having reduced body 
A
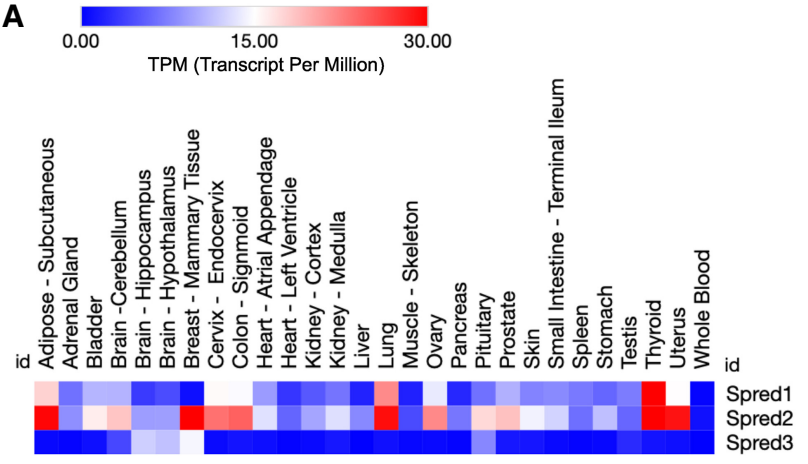

B
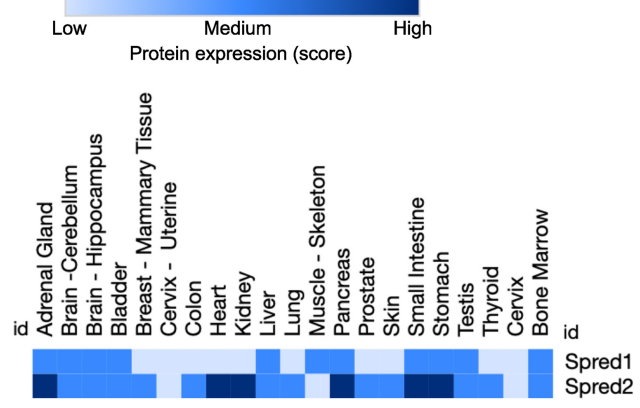

Figure 4. RNA and protein expression of SPRED proteins. $(A)$ RNA expression of SPRED1, SPRED2, and SPRED3 across tissues from The Genotype Tissue Expression (GTEX) Project (https ://www.gtexportal.org/home). (B) Protein expression of SPRED1 and SPRED2 across tissues from The Human Protein Atlas (https://www.proteinatlas.org).

length and weight, and had smaller skeletons compared with wild-type littermates (Tuduce et al. 2010). SPRED2 ${ }^{-/-}$mice were smaller from birth and remained smaller throughout their lifetime, consistent with achondroplasia (dwarfism), a condition caused by activating mutations in FGFR3. FGF and FGFR3 signaling play major roles in the regulation of bone growth in both mice and humans. Indeed, FGFR3-induced Ras-MAPK activity is a negative regulator of bone growth (Colvin et al. 1996). Loss of SPRED2 in mice chondrocytes resulted in increased ERK1/2 phosphorylation in response to FGF, which likely inhibited chondrocyte differentiation and consequently bone growth (Bundschu et al. 2005). In another SPRED $2^{-/-}$mouse model, generated by deleting exons encoding for KBD and SPR domain, adult mice appeared healthy with no apparent abnormalities in most organs (Nobuhisa et al. 2004). However, SPRED2 loss resulted in a significant increase in megakaryocytes, granulocytes, and hematopoietic cells (Nobuhisa et al. 2004). These results suggest that SPRED2 regulates hematopoiesis in the aorta-gonad-mesonephros by regulating cKit-mediated Ras-MAPK signaling during hematopoiesis.

The relatively mild phenotype of both SPRED1 and SPRED2 knockout mice may be due to redundancy when they are coexpressed in various organs. Double knockout of SPRED1 and SPRED2, generated by back-

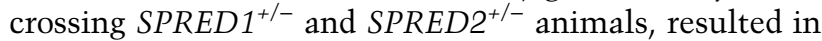
embryonic lethality (Taniguchi et al. 2007a). SPRED 1 ${ }^{+/-}$;
$S P R E D 2^{+/-}$double heterozygotes were healthy and fertile. SPRED 1 ${ }^{+/-}$; SPRED $2^{-/-}$were smaller, consistent with the dwarfism phenotype of SPRED2 knockout mice. SPRED1 $1^{-/-}$; SPRED2 $2^{+/-}$were born at severely sub-Mendelian frequencies, but several natal mice appeared sick and often died within a few months from uncharacterized causes. Most SPRED1 $1^{-/-}$; SPRED2 $2^{-/-}$embryos died due to severe subcutaneous hemorrhage and edema between E12.5 to E15.5. This phenotype resembles mouse embryos lacking Syk, SLP-76, or PLC $\gamma-2$, which are hematopoietic intracellular signaling proteins important for separation of lymphatic vessels from blood vessels (Abtahian et al. 2003). Together, these suggest that lymphatic vessel development is abnormal in SPRED1/2 doubleknockout embryos. In vitro, lymphatic endothelial cells from SPRED1/2 double knockout embryos proliferated more than wild-type cells. These lymphatic endothelial cells also exhibited stronger ERK activation following VEGF-C stimulation compared with wild type (Taniguchi et al. 2007a). Together, these results suggest that SPRED1 and SPRED2 are critical for the separation of lymphatic vessels from the parental vein by regulating VEGFR-3 induced Ras activation. Interestingly, lymphatic abnormalities commonly occur in patients with RASopathies, which further highlights the role of Ras-MAPK signaling in lymphatic vessels (Sevick-Muraca and King 2014).

Despite having a shared SPR domain, SPRED knockout mouse models have a distinct phenotype from SPROUTY knockout mouse models, except shared features with SPRED2 and SPROUTY4 knockout, both of which develop dwarfism (summarized in Table 2).

\section{Drosophila models}

Only one homolog of SPRED has been identified in Drosophila. Habituation deficits were reported in flies with neuron-specific knockdown of SPRED (Fenckova et al. 2019). Habituation is a form of learning that allows an organism's initial response to gradually decline following frequently repeated stimuli (Kimmel 1973). In humans, habituation deficits have been reported in behavioral disorders (Swartz et al. 2013; Ethridge et al. 2016). This phenotype relates to the behavioral deficits observed in SPRED1 knockout mice and Legius syndrome patients. Furthermore, knockdown of neurofibromin or expression of constitutively active Ras mutant recapitulated habituation deficiencies resulting from SPRED1 loss. Additionally, SPRED is involved in photoreceptor cell specification in Drosophila eye development (Demille et al. 1996); however, the role of SPRED in Drosophila development has not yet been elucidated.

\section{Disease}

\section{Developmental disorders}

Legius syndrome (LS) is an autosomal dominant condition characterized by multiple café au lait spots, axillary freckling, macrocephaly, and Noonan-like craniofacial 
Table 2. SPRED and Sprouty mouse models

\begin{tabular}{|c|c|c|}
\hline Genotype & Phenotype & References \\
\hline \multirow[t]{3}{*}{$\mathrm{SPRED}^{-/-}$} & $\begin{array}{l}\text { Shortened face, lower body weight, and allergen-induced airway } \\
\text { eosinophilia from IL-5-mediated eosinophil proliferation }\end{array}$ & Brems et al. 2007 \\
\hline & Spatial learning and memory defects from impaired hippocampal functions & Denayer et al. 2008 \\
\hline & Pigmentary abnormalities and shortened face & Tadokoro et al. 2018 \\
\hline \multirow[t]{2}{*}{ SPRED $2^{-/-}$} & Dwarfism from increased FGFR signaling in chondrocytes & Bundschu et al. 2005 \\
\hline & $\begin{array}{l}\text { Increase proliferation of megakaryocytes, granulocytes, and hematopoietic } \\
\text { cells }\end{array}$ & Nobuhisa et al. 2004 \\
\hline SPRED $1^{-/-}$SPRED $2^{-/-}$ & $\begin{array}{l}\text { Embryonic lethal between E12.5-E15.5 due to severe subcutaneous } \\
\text { hemorrhage and edema }\end{array}$ & Taniguchi et al. 2007a \\
\hline SPROUTY1 $1^{-/-}$ & Kidney and ureteric bud defects from improper branching morphogenesis & Basson et al. 2005, 2006 \\
\hline \multirow[t]{2}{*}{ SPROUTY2 $^{-/-}$} & $\begin{array}{l}\text { Viable with shortened life span (median survival 3-4 wk) and hearing loss } \\
\text { from perturbations in organ of Corti cytoarchitecture }\end{array}$ & Shim et al. 2005 \\
\hline & $\begin{array}{l}\text { Viable with shortened life span and severe gastrointestinal phenotype } \\
\text { characterized by enteric nerve dysplasia due to GDNF hyperactivity }\end{array}$ & Taketomi et al. 2005 \\
\hline $\begin{array}{l}\text { SPROUTY1 }{ }^{-/-} \\
\text {SPROUTY2 } \\
-/-\end{array}$ & $\begin{array}{l}\text { Highly disorganized palatial rugae from disrupted submandibular gland } \\
\text { epithelial development }\end{array}$ & $\begin{array}{l}\text { Economou et al. } 2012 \text {; } \\
\text { Knosp et al. } 2015\end{array}$ \\
\hline SPROUTY4 ${ }^{-1-}$ & Dwarfism and polysyndactyly from hyperactivation of FGF signaling & Taniguchi et al. 2007b \\
\hline $\begin{array}{l}\text { SPROUTY2 } 2^{-1-} \\
\text { SPROUTY4 } 4^{-1-}\end{array}$ & $\begin{array}{l}\text { Embryonic lethal by E12.5 with craniofacial, limb, and lung morphogenesis } \\
\text { abnormalities }\end{array}$ & $\begin{array}{l}\text { Taniguchi et al. 2007b, } \\
2009\end{array}$ \\
\hline $\begin{array}{l}\text { SPROUTY2 }^{+/-} \\
\text {SPROUTY } 4^{-/-}\end{array}$ & $\begin{array}{l}\text { Tusk-like incisor in the lower jaw due to presence of enamel on lingual } \\
\text { surface }\end{array}$ & $\begin{array}{l}\text { Boran et al. 2009; Klein } \\
\quad \text { et al. } 2008\end{array}$ \\
\hline
\end{tabular}

dysmorphia in some individuals. Other frequently observed features are learning and behavioral problems (Brems et al. 2007; Pasmant et al. 2009). The disorder is caused by loss-of-function mutations in the SPRED1 gene. The clinical phenotype of LS patients resembles a mild version of neurofibromatosis type I (NF1). NF1 is caused by loss-of-function mutations in the NF1 gene. Some of the phenotypes associated with NF1 are due to haploinsufficiency, such as developmental problems and learning disorders. Others are caused by loss of the wildtype allele to generate clonal growth of café au lait macules and benign neurofibromas, some of which often progress to malignant tumors of the peripheral and central nervous system (Riccardi 1992). Both NF1 and LS are RASopathies; syndromes caused by germline mutations in genes coding for proteins that regulate the Ras-MAPK pathway resulting in hyperactive signaling (Tidyman and Rauen 2009).

Sequencing of LS syndrome patients identified that most SPRED1 mutations result in protein truncations, although missense mutations and deletions also occur (Fig. 5A; Brems et al. 2007; Brems and Legius 2013). Biochemical analysis of some EVH-1 missense mutations showed disruption of the interaction with neurofibromin, while SPR mutations fail to localize to the membrane (Stowe et al. 2012; Hirata et al. 2016; Führer et al. 2017). However, missense mutations also map to regions of SPRED1 whose functions in regulating Ras are not yet clear (Fig. 5B; Sumner et al. 2011).

Consistent with pigmentation abnormalities found in knockout mice (Tadokoro et al. 2018), café au lait macules occur in all LS patients. Development of café au lait macules requires a second-hit mutation on the wild-type SPRED1 allele, such that the melanocytes are devoid of SPRED1 (Brems et al. 2007). These findings are consistent with café au lait macules in NF1 patients that also involve biallelic NF1 loss (Schepper et al. 2008).

Mutations in SPRED2 and SPRED3 have not been reported to cause developmental disorders in humans. Due to the overlapping functions of SPRED family proteins, it is likely that loss of function of either SPRED2 or SPRED3 does not cause a developmental phenotype because the other family members compensate for this loss. However, the emerging use of high-throughput sequencing in clinical genetics could reveal syndromes caused by these genes. Perhaps SPRED2 mutations could be associated with mild

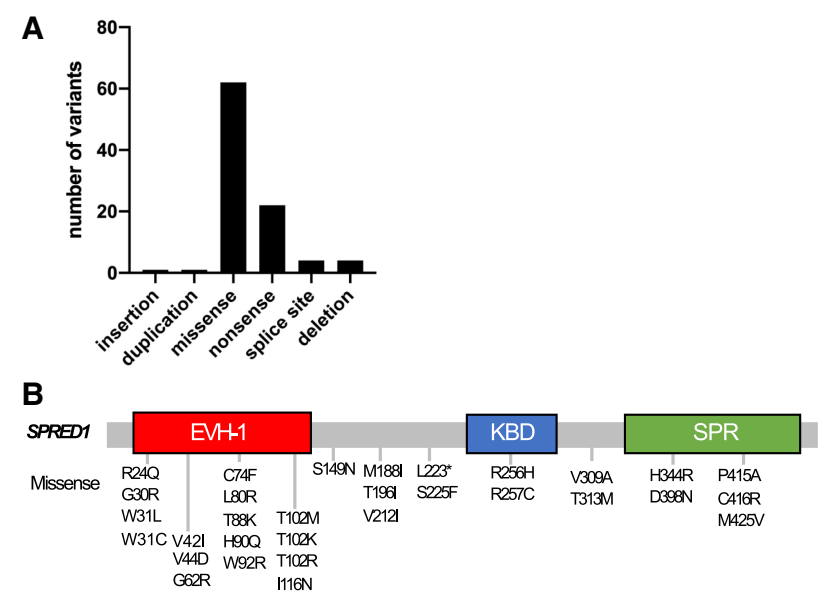

Figure 5. SPRED1 mutations found in Legius syndrome. (A) Frequency of each SPRED1 mutation variants found in Legius syndrome patients (http://arup.utah.edu/database/SPRED1/ SPRED1_welcome.php). (B) Missense mutations identified in patients with Legius syndrome. 
achondroplasia since loss of SPRED2 in mice results in dwarfism (Bundschu et al. 2005).

\section{Cancer}

Hyperactivation of Ras-MAPK signaling contributes to the proliferation, survival, metastasis, and many other traits characteristic of tumor cells. Therefore, negative regulators of this pathway have been observed to protect against tumorigenesis. SPRED and Sprouty proteins are putative tumor suppressors due to their ability to downregulate Ras-MAPK signaling (Kawazoe and Taniguchi 2019). By binding and translocating neurofibromin to the plasma membrane, SPRED may play a critical role in regulating cellular levels of Ras-GTP in many contexts (Stowe et al. 2012). Hence, loss of SPRED in tumor tissue likely permits hyperactivation of Ras signaling, which contributes to driving tumor growth and invasion.

SPRED1 mutations occur in $\sim 2 \%$ of cancers (TCGA). The most common alterations are deletions, truncations, and missense mutations (Fig. 6A). Currently, there are no known mutational hotspots for SPRED1 (Fig. 6B); however, biochemical studies have shown that some EVH-1 and SPR missense mutations result in defective neurofibromin binding or membrane localization (Dunzendorfer-Matt et al. 2016; Hirata et al. 2016). Furthermore, some of the SPRED1 missense mutations in cancer have also been found in Legius syndrome. Similarly, there are no known mutational hotspots for SPRED2 (Fig. 6C). Further biochemical characterization is necessary to determine the biological significance of these mutations. Finally, the lower frequency of SPRED3 mutations in cancer may relate to its restricted tissue expression (Figs. 4A, 6D).

Individuals with Legius syndrome have a predisposition for pediatric leukemia resulting from loss of heterozygosity (Pasmant et al. 2009). Likewise, NF1 is associated with a predisposition to juvenile myelomonocytic leukemia (JMML) and acute lymphoblastic leukemia (ALL) (Stiller et al. 1994), since loss of SPRED1 binding partner, neurofibromin, also results in a similar hyperactivation of Ras signaling. Furthermore, SPRED1 somatic mutations occurred in $2 \%$ of pediatric acute leukemias, and SPRED1 expression was significantly decreased in pediatric AML and T-ALL (Pasmant et al. 2015). In those samples, decreased SPRED1 protein and RNA levels correlated to high ERK phosphorylation (Pasmant et al. 2015).

SPRED1 loss was also found as a driver of mucosal melanoma where $37 \%$ of mucosal melanomas examined

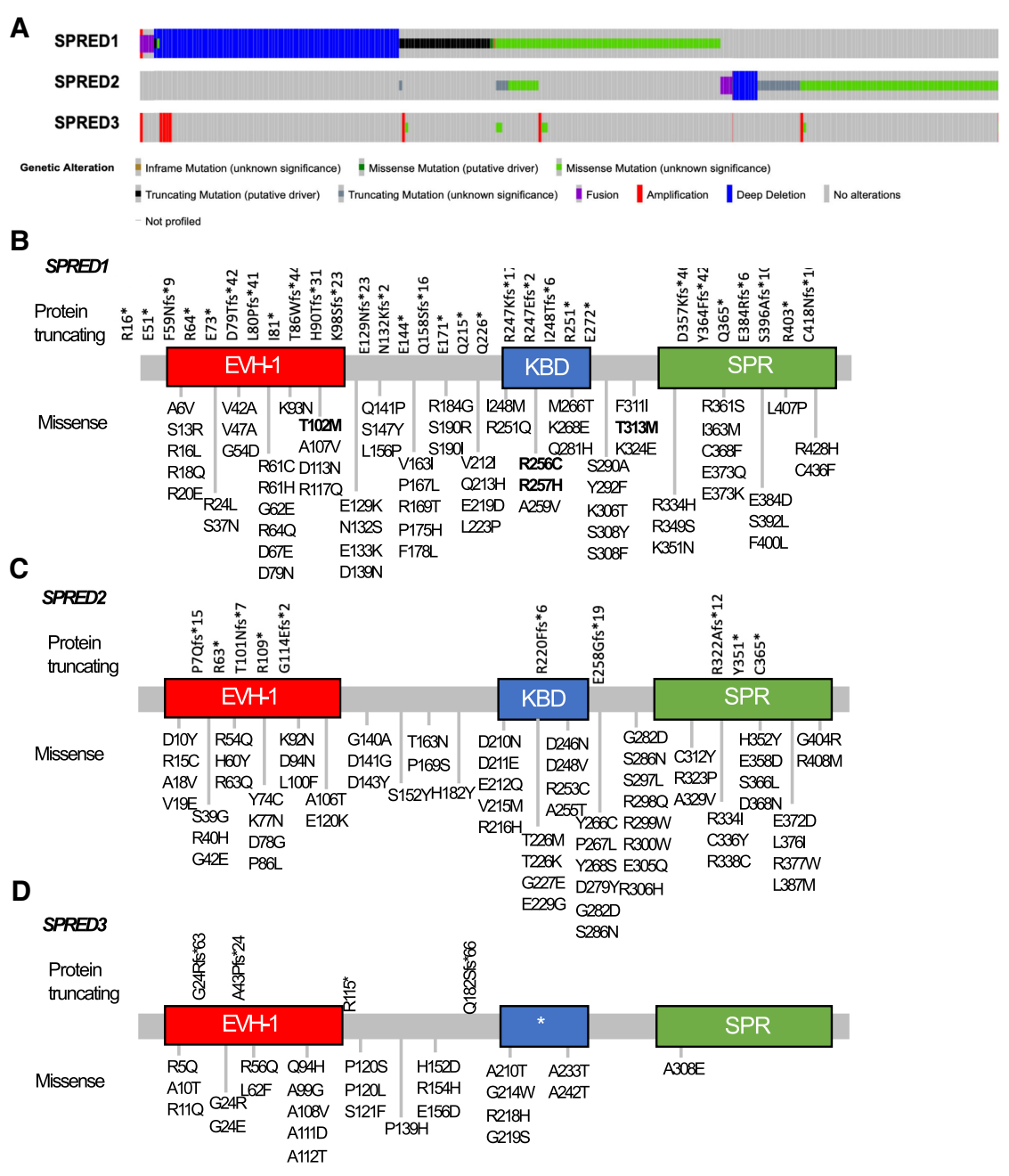

Figure 6. Mutations in SPRED proteins in human cancers. $(A)$ Genetic alterations in SPREDs found in cancer (adapted from data from cBioPortal, https://www.cbioportal .org). (B) Truncating (top) and missense (bottom) mutations in SPRED1 found in cancer (TCGA; https://portal.gdc.cancer .gov). (C) Truncating (top) and missense (bottom) mutations in SPRED2 found in cancer (TCGA). (D) Truncating (top) and missense (bottom) mutations in SPRED3 found in cancer (TCGA). 
showed SPRED1 loss of function (Ablain et al. 2018). In most cases, melanomas were triple wild type for $B R A F$, $R A S$, and NF1. Notably, $c$-KIT activating alterations co-occurred in $30 \%$ of cases with SPRED1 loss (Ablain et al. 2018). This suggests that SPRED1 loss may cooperate with oncogenic events that activate the Ras-MAPK pathway.

In other cancers, although SPRED1 is not mutated, SPRED1 mRNA and/or protein levels are reduced (Yoshida et al. 2006; Kachroo et al. 2013; Wang et al. 2017; Jiang et al. 2018). In oral squamous cell carcinoma tumor tissues, SPRED1 is significantly down-regulated due to the up-regulation of miR182 in malignant tissues that directly targets SPRED1 (Wang et al. 2017). Likewise, SPRED1 is significantly down-regulated in $\mathrm{ER}^{+}$breast cancer due to the up-regulation of miR-196a that directly targets SPRED1 (Jiang et al. 2018). In hepatocellular carcinoma, SPRED1 and SPRED2 were simultaneously down-regulated tumor tissue compared with noncancerous tissue (Yoshida et al. 2006). In prostate cancer, SPRED2 expression levels were significantly reduced in tumor tissue relative to benign glands, and SPRED2 expression was significantly down-regulated in grades 4 and 5 tumors (Kachroo et al. 2013). In all cases, down-regulation of SPRED correlated with increased ERK phosphorylation.

SPRED1 and NF1 mutations tend to be mutually exclusive with gain-of-function EGFR mutations in lung adenocarcinoma (Collisson et al. 2014). In a model system expressing oncogenic EGFR L858R, SPRED1 was highly phosphorylated at S105 (Yan et al. 2020), which is in close proximity to T102, which is mutated to arginine in LS (Messiaen et al. 2009). Mutation of SPRED1 S105 resulted in disruption in neurofibromin-SPRED1 binding and augmented cell proliferation in K562 cells (Yan et al. 2020). Furthermore, SPRED1 S105 phosphorylation was found to be elevated in four additional EGFR-mutant cancer cell lines (PC9, U2OS, A431, and H1975) (Yan et al. 2020). To date, this is the only known mechanism by which RTK signaling directly regulates neurofibrominSPRED1 interaction. Thus, it raises the possibility that SPRED1 function is normally regulated in response to signals to modulate Ras-GTP levels and downstream signal transduction.

\section{Summary and future directions}

SPRED proteins are crucial regulators of Ras-MAPK signaling. Although SPRED and Sprouty proteins share an SPR domain, each family regulates Ras through distinct yet complementary mechanisms. Sprouty limits GTP loading of Ras, while SPRED promotes Ras-GTP hydrolysis. Despite these findings, numerous unresolved questions remain regarding the function, regulation, interactions, and signaling control of SPRED proteins.

While the role of the EVH-1 and SPR domains in recruitment of neurofibromin to the membrane are clear, the role of the KBD in SPRED is not well understood. Specifically, what is the context of c-Kit binding to SPRED? Can SPRED bind other RTKs besides c-Kit? Is c-Kit binding necessary for efficient Ras inhibition? Does SPRED binding inhibit c-Kit signaling, especially Ras activation? Furthermore, c-Kit signaling is important for melanocyte development. Café au lait macules and axillary freckling are features of Legius syndrome and NF1 that affect melanocytes. Thus, is the interaction between SPRED and cKit what limits Legius syndrome phenotype to melanocytes, compared with other tissues, as in NF1?

The regulation of SPRED and neurofibromin binding needs to be further defined. Signals that regulate SPRED binding to the plasma membrane are not yet known. Sprouty proteins are regulated by phosphorylation and dephosphorylation of a conserved tyrosine. Hence, it seems likely that SPRED activity is regulated by phosphorylation, as well as dimerization and association with other protein partners. At present, little is known about the physiological functions of SPRED3. SPRED3 has the least sequence similarity to other SPRED proteins and exhibits reduced binding to neurofibromin and does not bind c-Kit (Kato et al. 2003; Hirata et al. 2016).

Generation of SPRED3 knockout mice is important to understand its biological function and further inform shared mechanisms of regulation for SPRED proteins. Understanding how SPRED proteins are regulated and in what signaling context will help the development of new therapies for RASopathies and cancers resulting from hyperactive Ras signaling.

\section{Competing interest statement}

F.M. is a consultant for the following companies: Aduro Biotech; Amgen; Daiichi Ltd.; Ideaya Biosciences; Kura Oncology; Leidos Biomedical Research, Inc.; PellePharm; Pfizer, Inc.; PMV Pharma; Portola Pharmaceuticals; and Quanta Therapeutics. F.M. is a consultant and cofounder for the following companies (with ownership interest, including stock options): BridgeBio; DNAtrix, Inc.; Olema Pharmaceuticals, Inc.; and Quartz. F.M. is Scientific Director of the NCI Ras Initiative at Frederick National Laboratory for Cancer Research/Leidos Biomedical Research, Inc.

\section{Acknowledgments}

The data used for the analyses described here were obtained from the GTEx Portal on May 4, 2020, and the Human Protein Atlas on May 4, 2020. Funding was provided by the National Institutes of Health (5R35CA197709) and the US Department of Defense (W81XWH2010129).

\section{References}

Ablain J, Xu M, Rothschild H, Jordan RC, Mito JK, Daniels BH, Bell CF, Joseph NM, Wu H, Bastian BC, et al. 2018. Human tumor genomics and zebrafish modeling identify SPRED1 loss as a driver of mucosal melanoma. Science 362: 1055-1060. doi:10.1126/science.aau6509

Abtahian F, Guerriero A, Sebzda E, Lu M-M, Zhou R, Mocsai A, Myers EE, Huang B, Jackson DG, Ferrari VA, et al. 2003. Regulation of blood and lymphatic vascular separation by signaling proteins SLP-76 and Syk. Science 299: 247-251. doi:10 $.1126 /$ science. 1079477 
Ball LJ, Jarchau T, Oschkinat H, Walter U. 2002. EVH1 domains: structure, function and interactions. Febs Lett 513: 45-52. doi:10.1016/S0014-5793/01)03291-4

Basson MA, Akbulut S, Watson-Johnson J, Simon R, Carroll TJ, Shakya R, Gross I, Martin GR, Lufkin T, McMahon AP, et al. 2005. Sproutyl is a critical regulator of GDNF/RET-mediated kidney induction. Dev Cell 8: 229-239. doi:10.1016/j .devcel.2004.12.004

Basson MA, Watson-Johnson J, Shakya R, Akbulut S, Hyink D, Costantini FD, Wilson PD, Mason IJ, Licht JD. 2006. Branching morphogenesis of the ureteric epithelium during kidney development is coordinated by the opposing functions of GDNF and Sprouty1. Dev Biol 299: 466-477. doi:10.1016/j .ydbio.2006.08.051

Bastiani M, Parton RG. 2010. Caveolae at a glance. J Cell Sci 123: 3831-3836. doi:10.1242/jcs.070102

Boran T, Peterkova R, Lesot H, Lyons DB, Peterka M, Klein OD. 2009. Temporal analysis of ectopic enamel production in incisors from sprouty mutant mice. I Exp Zoology Part B Mol Dev Evol 312B: 473-485. doi:10.1002/jez.b.21254

Bosc DG, Goueli BS, Janknecht R. 2001. HER2/Neu-mediated activation of the ETS transcription factor ER81 and its target gene MMP-1. Oncogene 20: 6215-6224. doi:10.1038/sj.onc .1204820

Brems H, Legius E. 2013. Legius syndrome, an update.molecular pathology of mutations in SPRED1. Keio I Medicine 62: 107-112. doi:10.2302/kjm.2013-0002-RE

Brems H, Chmara M, Sahbatou M, Denayer E, Taniguchi K, Kato R, Somers R, Messiaen L, Schepper SD, Fryns J-P, et al. 2007. Germline loss-of-function mutations in SPRED1 cause a neurofibromatosis 1-like phenotype. Nat Genet 39: 1120-1126. doi:10.1038/ng2113

Buday L, Downward J. 1993. Epidermal growth factor regulates p2 $1^{\text {ras }}$ through the formation of a complex of receptor, Grb2 adapter protein, and SOS nucleotide exchange factor. Cell 73: 611-620. doi:10.1016/0092-8674(93)90146-H

Bundschu K, Knobeloch K-P, Ullrich M, Schinke T, Amling M, Engelhardt CM, Renné T, Walter U, Schuh K. 2005. Gene disruption of spred-2 causes dwarfism. J Biol Chem 280: 2857228580. doi:10.1074/jbc.M503640200

Butland SL, Sanders SS, Schmidt ME, Riechers S-P, Lin DTS, Martin DDO, Vaid K, Graham RK, Singaraja RR, Wanker EE, et al. 2014. The palmitoyl acyltransferase HIP14 shares a high proportion of interactors with huntingtin: implications for a role in the pathogenesis of Huntington's disease. Hum Mol Genet 23: 4142-4160. doi:10.1093/hmg/ddu137

Casci T, Vinós J, Freeman M. 1999. Sprouty, an intracellular inhibitor of Ras signaling. Cell 96: 655-665. doi:10.1016/ S0092-8674(00)80576-0

Cerami E, Gao J, Dogrusoz U, Gross BE, Sumer SO, Aksoy BA, Jacobsen A, Byrne CJ, Heuer ML, Larsson E, et al. 2012. The cBio cancer genomics portal: an open platform for exploring multidimensional cancer genomics data. Cancer Discov 2: 401-404. doi:10.1158/2159-8290.CD-12-0095

Collisson EA, Campbell JD, Brooks AN, Berger AH, Lee W, Chmielecki J, Beer DG, Cope L, Creighton CI, Danilova L, et al. 2014. Comprehensive molecular profiling of lung adenocarcinoma. Nature 511: 543-550. doi:10.1038/nature13385

Colvin JS, Bohne BA, Harding GW, McEwen DG, Ornitz DM. 1996. Skeletal overgrowth and deafness in mice lacking fibroblast growth factor receptor 3. Nat Genet 12: 390-397. doi:10 .1038/ng0496-390

Costa RM, Federov NB, Kogan JH, Murphy GG, Stern J, Ohno M, Kucherlapati R, Jacks T, Silva AJ. 2002. Mechanism for the learning deficits in a mouse model of neurofibromatosis type 1. Nature 415: 526-530. doi:10.1038/nature711

Cui Y, Costa RM, Murphy GG, Elgersma Y, Zhu Y, Gutmann DH, Parada LF, Mody I, Silva AJ. 2008. Neurofibromin regulation of ERK signaling modulates GABA release and learning. Cell 135: 549-560. doi:10.1016/j.cell.2008.09.060

Demille MMC, Kimmel BE, Rubin GM. 1996. A Drosophila gene regulated by rough and glass shows similarity to ena and VASP. Gene 183: 103-108. doi:10.1016/S0378-1119(96)00506-9

Denayer E, Ahmed T, Brems H, Woerden GV, Borgesius NZ, Callaerts-Vegh Z, Yoshimura A, Hartmann D, Elgersma Y, $D^{\prime}$ Hooge $R$, et al. 2008. Spred1 Is required for synaptic plasticity and hippocampus-dependent learning. I Neurosci 28: 14443-14449. doi:10.1523/JNEUROSCI.4698-08.2008

Dry JR, Pavey S, Pratilas CA, Harbron C, Runswick S, Hodgson D, Chresta C, McCormack R, Byrne N, Cockerill M, et al. 2010. Transcriptional pathway signatures predict MEK addiction and response to selumetinib (AZD6244). Cancer Res 70: 2264-2273. doi:10.1158/0008-5472.CAN-09-1577

Dunzendorfer-Matt T, Mercado EL, Maly K, McCormick F, Scheffzek K. 2016. The neurofibromin recruitment factor Spred1 binds to the GAP related domain without affecting Ras inactivation. Proc Natl Acad Sci 113: 7497-7502. doi:10 $.1073 /$ pnas. 1607298113

Economou AD, Ohazama A, Porntaveetus T, Sharpe PT, Kondo S, Basson MA, Gritli-Linde A, Cobourne MT, Green JBA. 2012. Periodic stripe formation by a Turing mechanism operating at growth zones in the mammalian palate. Nat Genet 44: 348-351. doi:10.1038/ng.1090

Engelhardt CM, Bundschu K, Messerschmitt M, Renné T, Walter U, Reinhard M, Schuh K. 2004. Expression and subcellular localization of spred proteins in mouse and human tissues. Histochem Cell Biol 122: 527-538. doi:10.1007/s00418-004-0725-6

Ethridge LE, White SP, Mosconi MW, Wang J, Byerly MJ, Sweeney JA. 2016. Reduced habituation of auditory evoked potentials indicate cortical hyper-excitability in fragile $\mathrm{X}$ syndrome. Trans1 Psychiat 6: e787. doi:10.1038/tp.2016.48

Fenckova M, Blok LER, Asztalos L, Goodman DP, Cizek P, Singgih EL, Glennon JC, IntHout J, Zweier C, Eichler EE, et al. 2019. Habituation learning is a widely affected mechanism in Drosophila models of intellectual disability and autism spectrum disorders. Biol Psychiat 86: 294-305. doi:10.1016/j.biopsych .2019.04.029

Führer S, Ahammer L, Ausserbichler A, Scheffzek K, Dunzendorfer-Matt T, Tollinger M. 2017. NMR resonance assignments of the EVH1 domain of neurofibromin's recruitment factor Spred1. Biomol Nmr Assigm 11: 305-308. doi:10.1007/ s12104-017-9768-1

Hacohen N, Kramer S, Sutherland D, Hiromi Y, Krasnow MA. 1998. Sprouty encodes a novel antagonist of FGF signaling that patterns apical branching of the Drosophila airways. Cell 92: 253-263. doi:10.1016/S0092-8674(00)80919-8

Hall AB, Jura N, DaSilva J, Jang YJ, Gong D, Bar-Sagi D. 2003. Hspry2 Is targeted to the ubiquitin-dependent proteasome pathway by c-Cbl. Curr Biol 13: 308-314. doi:10.1016/ S0960-9822(03)00086-1

Hanafusa H, Torii S, Yasunaga T, Nishida E. 2002. Sprouty1 and Sprouty2 provide a control mechanism for the Ras/MAPK signalling pathway. Nat Cell Biol 4: 850-858. doi:10.1038/ncb867

Hanafusa H, Torii S, Yasunaga T, Matsumoto K, Nishida E. 2004. Shp2, an SH2-containing protein-tyrosine phosphatase, positively regulates receptor tyrosine kinase signaling by dephosphorylating and inactivating the inhibitor Sprouty. I Biol Chem 279: 22992-22995. doi:10.1074/jbc.M312498200 
Harmer NJ, Sivak JM, Amaya E, Blundell TL. 2005. 1.15 å crystal structure of the $X$. tropicalis Spred1 EVH1 domain suggests a fourth distinct peptide-binding mechanism within the EVH1 family. Febs Lett 579: 1161-1166. doi:10.1016/j.febslet.2004 .11 .114

Hirata Y, Brems H, Suzuki M, Kanamori M, Okada M, Morita R, Llano-Rivas I, Ose T, Messiaen L, Legius E, et al. 2016. Interaction between a domain of the negative regulator of the RasERK pathway, SPRED1 protein, and the GTPase-activating protein-related domain of neurofibromin Is implicated in Legius syndrome and neurofibromatosis type 1. J Biol Chem 291: 3124-3134. doi:10.1074/jbc.M115.703710

Hyman SL, Shores A, North KN. 2005. The nature and frequency of cognitive deficits in children with neurofibromatosis type 1. Neurology 65: 1037-1044. doi:10.1212/01.wnl.00001793 03.72345.ce

Impagnatiello MA, Weitzer S, Gannon G, Compagni A, Cotten M, Christofori G. 2001. Mammalian sprouty-1 and -2 are membrane-anchored phosphoprotein inhibitors of growth factor signaling in endothelial cells. J Cell Biol 152: 1087-1098. doi:10.1083/jcb.152.5.1087

Inoue H, Kato R, Fukuyama S, Nonami A, Taniguchi K, Matsumoto K, Nakano T, Tsuda M, Matsumura M, Kubo M, et al. 2005. Spred-1 negatively regulates allergen-induced airway eosinophilia and hyperresponsiveness. I Exp Medicine 201: 7382. doi: $10.1084 / \mathrm{jem} .20040616$

Jané-Valbuena J, Widlund HR, Perner S, Johnson LA, Dibner AC, Lin WM, Baker AC, Nazarian RM, Vijayendran KG, Sellers WR, et al. 2010. An oncogenic role for ETV1 in melanoma. Cancer Res 70: 2075-2084. doi:10.1158/0008-5472.CAN-09-3092

Janknecht R. 1996. Analysis of the ERK-stimulated ETS transcription factor ER81. Mol Cell Biol 16: 1550-1556.

Jiang C-F, Shi Z-M, Li D-M, Qian Y-C, Ren Y, Bai X-M, Xie Y-X, Wang L, Ge X, Liu W-T, et al. 2018. Estrogen-induced miR196a elevation promotes tumor growth and metastasis via targeting SPRED1 in breast cancer. Mol Cancer 17: 83. doi:10 .1186/s12943-018-0830-0

Kachroo N, Valencia T, Warren AY, Gnanapragasam VJ. 2013. Evidence for downregulation of the negative regulator SPRED2 in clinical prostate cancer. Brit I Cancer 108: 597-601. doi:10.1038/bjc.2012.507

Kato R, Nonami A, Taketomi T, Wakioka T, Kuroiwa A, Matsuda Y, Yoshimura A. 2003. Molecular cloning of mammalian Spred-3 which suppresses tyrosine kinase-mediated Erk activation. Biochem Bioph Res Co 302: 767-772. doi:10.1016/ S0006-291X(03)00259-6

Kawazoe T, Taniguchi K. 2019. The sprouty/spred family as tumor suppressors: coming of age. Cancer Sci 110: 1525-1535. doi:10.1111/cas.13999

Kimmel HD. 1973. Habituation, habituability, and conditioning. In Habitutuation: behavioral studies, volume 1 (ed. Peeke HVS, Herz MJ), pp. 219-238. Academic Press, New York.

King JAJ, Straffon AFL, D'Abaco GM, Poon CLC ISTT, Smith CM, Buchert M, Corcoran NM, Hall NE, Callus BA, et al. 2005. Distinct requirements for the Sprouty domain for functional activity of Spred proteins. Biochem I 388: 445-454. doi:10.1042/BJ20041284

Klein OD, Lyons DB, Balooch G, Marshall GW, Basson MA, Peterka M, Boran T, Peterkova R, Martin GR. 2008. An FGF signaling loop sustains the generation of differentiated progeny from stem cells in mouse incisors. Development 135: 377385. doi:10.1242/dev.015081

Knosp WM, Knox SM, Lombaert IMA, Haddox CL, Patel VN, Hoffman MP. 2015. Submandibular parasympathetic gangliogenesis requires Sprouty-dependent Wnt signals from epithe- lial progenitors. Dev Cell 32: 667-677. doi:10.1016/j.devcel .2015 .01 .023

Lim J, Yusoff P, Wong ESM, Chandramouli S, Lao D-H, Fong CW, Guy GR. 2002. The cysteine-rich Sprouty translocation domain targets mitogen-activated protein kinase inhibitory proteins to phosphatidylinositol 4,5-bisphosphate in plasma membranes. Mol Cell Biol 22: 7953-7966. doi:10.1128/MCB .22.22.7953-7966.2002

Martin GA, Viskoohil D, Bollag G, McCabe PC, Crosier WJ, Haubruck H, Conroy L, Clark R, O'Connell P, Cawthon RM, et al. 1990. The GAP-related domain of the neurofibromatosis type 1 gene product interacts with ras p21. Cell 63: 843-849. doi:10 $.1016 / 0092-8674(90) 90150-\mathrm{D}$

Mason JM, Morrison DJ, Bassit B, Dimri M, Band H, Licht JD, Gross I. 2004. Tyrosine phosphorylation of sprouty proteins regulates their ability to inhibit growth factor signaling: a dual feedback loop. Mol Biol Cell 15: 2176-2188. doi:10 .1091/mbc.E03-07-0503

Messiaen L, Yao S, Brems H, Callens T, Sathienkijkanchai A, Denayer E, Spencer E, Arn P, Babovic-Vuksanovic D, Bay C, et al. 2009. Clinical and mutational spectrum of neurofibromatosis type 1-like syndrome. JAMA 302: 2111-2118. doi:10 $.1001 /$ jama.2009.1663

Nan X, Tamgüney TM, Collisson EA, Lin L-J, Pitt C, Galeas J, Lewis S, Gray JW, McCormick F, Chu S. 2015. Ras-GTP dimers activate the mitogen-activated protein kinase (MAPK) pathway. Proc Natl Acad Sci 112: 7996-8001. doi:10.1073/pnas .1509123112

Nobuhisa I, Kato R, Inoue H, Takizawa M, Okita K, Yoshimura A, Taga T. 2004. Spred-2 suppresses aorta-gonad-mesonephros hematopoiesis by inhibiting MAP kinase activation. I Exp Medicine 199: 737-742. doi:10.1084/jem.20030830

Nonami A, Taketomi T, Kimura A, Saeki K, Takaki H, Sanada T, Taniguchi K, Harada M, Kato R, Yoshimura A. 2005. The Sprouty-related protein, spred-1, localizes in a lipid raft/caveola and inhibits ERK activation in collaboration with caveolin-1. Genes Cells 10: 887-895. doi:10.1111/j.1365-2443.2005 .00886.x

Oh S, Shin S, Lightfoot SA, Janknecht R. 2013. 14-3-3 proteins modulate the ETS transcription factor ETV1 in prostate cancer. Cancer Res 73: 5110-5119. doi:10.1158/0008-5472 .CAN-13-0578

Ozaki K, Kadomoto R, Asato K, Tanimura S, Itoh N, Kohno M. 2001. ERK pathway positively regulates the expression of sprouty genes. Biochem Bioph Res Co 285: 1084-1088. doi:10.1006/bbrc.2001.5295

Packer LM, East P, Reis-Filho JS, Marais R. 2009. Identification of direct transcriptional targets of ${ }^{\mathrm{V} 600 \mathrm{E}} \mathrm{BRAF} / \mathrm{MEK}$ signalling in melanoma. Pigm Cell Melanoma R 22: 785-798. doi:10.1111/j .1755-148X.2009.00618.x

Pasmant E, Ballerini P, Lapillonne H, Perot C, Vidaud D, Leverger G, Landman-Parker J. 2009. SPRED1 disorder and predisposition to leukemia in children. Blood 114: 1131. doi:10.1182/ blood-2009-04-21850

Pasmant E, Gilbert-Dussardier B, Petit A, de Laval B, Luscan A, Gruber A, Lapillonne H, Deswarte C, Goussard P, Laurendeau I, et al. 2015. SPRED1, a RAS MAPK pathway inhibitor that causes Legius syndrome, is a tumour suppressor downregulated in paediatric acute myeloblastic leukaemia. Oncogene 34: 631-638. doi:10.1038/onc.2013.587

Peterson FC, Volkman BF. 2014. Diversity of polyproline recognition by EVH1 domains. Front Biosci 14: 833-846.

Pratilas CA, Taylor BS, Ye Q, Viale A, Sander C, Solit DB, Rosen N. 2009. V600EBRAF is associated with disabled feedback inhibition of RAF-MEK signaling and elevated transcriptional 
output of the pathway. Proc Natl Acad Sci 106: 4519-4524. doi:10.1073/pnas.0900780106

Ran L, Sirota I, Cao Z, Murphy D, Chen Y, Shukla S, Xie Y, Kaufmann MC, Gao D, Zhu S, et al. 2015. Combined inhibition of MAP kinase and KIT signaling synergistically destabilizes ETV1 and suppresses GIST tumor growth. Cancer Discov 5: 304-315. doi:10.1158/2159-8290.CD-14-0985

Riccardi VM. 1992. Piebaldism and neurofibromatosis 1. Pediatr Dermatol 10: 288. doi:10.1016/0045-9380(92)90053-2

Schepper SD, Maertens O, Callens T, Naeyaert J-M, Lambert J, Messiaen L. 2008. Somatic mutation analysis in NF1 café au lait spots reveals Two NF1 hits in the melanocytes. J Invest Dermatol 128: 1050-1053. doi:10.1038/sj.jid.5701095

Sevick-Muraca EM, King PD. 2014. Lymphatic vessel abnormalities arising from disorders of Ras signal transduction. Trends Cardiovas Med 24: 121-127. doi:10.1016/j.tcm.2013.09.004

Sherekar M, Han S-W, Ghirlando R, Messing S, Drew M, Rabara D, Waybright T, Juneja P, O'Neill H, Stanley CB, et al. 2020. Biochemical and structural analyses reveal that the tumor suppressor neurofibromin (NF1) forms a high-affinity dimer. J Biol Chem 295: 1105-1119. doi:10.1074/jbc.RA119.010934

Shim K, Minowada G, Coling DE, Martin GR. 2005. Sprouty2, a mouse deafness gene, regulates cell fate decisions in the auditory sensory epithelium by antagonizing FGF signaling. Dev Cell 8: 553-564. doi:10.1016/j.devcel.2005.02.009

Siljamäki E, Abankwa D. 2016. SPRED1 interferes with K-ras but Not H-ras membrane anchorage and signaling. Mol Cell Biol 36: 2612-2625. doi:10.1128/MCB.00191-16

Simanshu DK, Nissley DV, McCormick F. 2017. RAS proteins and their regulators in human disease. Cell 170: 17-33. doi:10.1016/j.cell.2017.06.009

Stiller C, Chessells J, Fitchett M. 1994. Neurofibromatosis and childhood leukaemia/lymphoma: a population-based UKCCSG study. Brit I Cancer 70: 969-972. doi:10.1038/bjc.1994.431

Stowe IB, Mercado EL, Stowe TR, Bell EL, Oses-Prieto JA, Hernández $\mathrm{H}$, Burlingame AL, McCormick F. 2012. A shared molecular mechanism underlies the human rasopathies legius syndrome and neurofibromatosis-1. Gene Dev 26: 14211426. doi:10.1101/gad.190876.112

Sumner K, Crockett DK, Muram T, Mallempati K, Best H, Mao R. 2011. The SPRED1 variants repository for Legius syndrome. G3 Genes Genomes Genetics 1: 451-456.

Swartz JR, Wiggins JL, Carrasco M, Lord C, Monk CS. 2013. Amygdala habituation and prefrontal functional connectivity in youth with autism spectrum disorders. I Am Acad Child Adolesc Psychiatry 52: 84-93. doi:10.1016/j.jaac.2012.10.012

Tadokoro Y, Hoshii T, Yamazaki S, Eto K, Ema H, Kobayashi M, Ueno M, Ohta K, Arai Y, Hara E, et al. 2018. Spredl safeguards hematopoietic homeostasis against diet-induced systemic stress. Cell Stem Cell 22: 713-725.e8. doi:10.1016/j.stem .2018.04.002

Taketomi T, Yoshiga D, Taniguchi K, Kobayashi T, Nonami A, Kato R, Sasaki M, Sasaki A, Ishibashi H, Moriyama M, et al. 2005. Loss of mammalian Sprouty2 leads to enteric neuronal hyperplasia and esophageal achalasia. Nat Neurosci 8: 855857. doi:10.1038/nn1485

Taniguchi K, Kohno R, Ayada T, Kato R, Ichiyama K, Morisada T, Oike Y, Yonemitsu Y, Maehara Y, Yoshimura A. 2007a. Spreds Are essential for embryonic lymphangiogenesis by regulating vascular endothelial growth factor receptor 3 signaling. Mol Cell Biol 27: 4541-4550. doi:10.1128/MCB.01600-06

Taniguchi K, Ayada T, Ichiyama K, Kohno R, Yonemitsu Y, Minami Y, Kikuchi A, Maehara Y, Yoshimura A. 2007b. Sprouty2 and Sprouty 4 are essential for embryonic morphogenesis and regulation of FGF signaling. Biochem Bioph Res Co 352: 896-902. doi:10.1016/j.bbrc.2006.11.107

Taniguchi K, Sasaki K, Watari K, Yasukawa H, Imaizumi T, Ayada T, Okamoto F, Ishizaki T, Kato R, Kohno R, et al. 2009. Suppression of Sproutys has a therapeutic effect for a mouse model of ischemia by enhancing angiogenesis. PLOS One 4: e5467. doi:10.1371/journal.pone.0005467

Terrell EM, Durrant DE, Ritt DA, Sealover NE, Sheffels E, SpencerSmith R, Esposito D, Zhou Y, Hancock JF, Kortum RL, et al. 2019. Distinct binding preferences between Ras and Raf family members and the impact on oncogenic Ras signaling. Mol Cell 76: 872-884.e5. doi:10.1016/j.molcel.2019.09.004

Tidyman WE, Rauen KA. 2009. The RASopathies: developmental syndromes of Ras/MAPK pathway dysregulation. Curr Opin Genet Dev 19: 230-236. doi:10.1016/j.gde.2009.04.001

Tong J, Elowe S, Nash P, Pawson T. 2003. Manipulation of EphB2 regulatory motifs and $\mathrm{SH} 2$ binding sites switches MAPK signaling and biological activity. J Biol Chem 278: 6111-6119. doi:10.1074/jbc.M208972200

Tuduce IL, Schuh K, Bundschu K. 2010. Spred2 expression during mouse development. Dev Dynam 239: 3072-3085. doi:10 $.1002 /$ dvdy.22432

Wakioka T, Sasaki A, Kato R, Shouda T, Matsumoto A, Miyoshi K, Tsuneoka M, Komiya S, Baron R, Yoshimura A. 2001. Spred is a sprouty-related suppressor of Ras signalling. Nature 412: 647-651. doi:10.1038/35088082

Wang J, Wang W, Li J, Wu L, Song M, Meng Q. 2017. Mir182 activates the Ras-MEK-ERK pathway in human oral cavity squamous cell carcinoma by suppressing RASA1 and SPRED1. Oncotargets Ther Volume 10: 667-679. doi:10.2147/OTT .S121864

Whitmarsh AJ. 2007. Regulation of gene transcription by mitogen-activated protein kinase signaling pathways. Biochimica Et Biophysica Acta Bba-Mol Cell Res 1773: 1285-1298. doi:10.1016/j.bbamcr.2006.11.011

Wright LP, Philips MR. 2006. Thematic review series: lipid posttranslational modifications. CAAX modification and membrane targeting of Ras. J Lipid Res 47: 883-891. doi:10.1194/ jlr.R600004-JLR200

Xie Y, Cao Z, Wong EWP, Guan Y, Ma W, Zhang JQ, Walczak EG, Murphy D, Ran L, Sirota I, et al. 2018. COP1-DET1-ETS axis regulates ERK transcriptome and sensitivity to MAPK inhibitors. J Clin Invest 128: 1442-1457. doi:10.1172/JCI94840

Xu G, O'Connell P, Viskochil D, Cawthon R, Robertson M, Culver M, Dunn D, Stevens J, Gesteland R, White R, et al. 1990. The neurofibromatosis type 1 gene encodes a protein related to GAP. Cell 62: 599-608. doi:10.1016/0092-8674(90|90024-9

Yan W, Markegard E, Dharmaiah S, Urisman A, Drew M, Esposito D, Scheffzek K, Nissley DV, McCormick F, Simanshu DK. 2020. Structural insights into the SPRED1-neurofibrominKRAS complex and disruption of SPRED1-neurofibromin interaction by oncogenic EGFR. Cell Rep 32: 107909. doi:10 .1016/j.celrep.2020.107909

Yoshida T, Hisamoto T, Akiba J, Koga H, Nakamura K, Tokunaga Y, Hanada S, Kumemura H, Maeyama M, Harada M, et al. 2006. Spreds, inhibitors of the Ras/ERK signal transduction, are dysregulated in human hepatocellular carcinoma and linked to the malignant phenotype of tumors. Oncogene 25: 6056-6066. doi:10.1038/sj.onc. 1209635

Yusoff P, Lao D-H, Ong SH, Wong ESM, Lim J, Lo TL, Leong HF, Fong CW, Guy GR. 2002. Sprouty2 inhibits the Ras/MAP kinase pathway by inhibiting the activation of Raf. J Biol Chem 277: 3195-3201. doi:10.1074/jbc.M108368200 


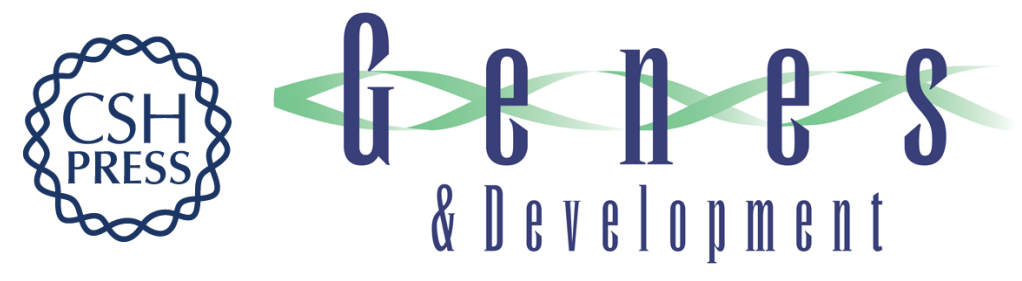

\section{SPRED proteins and their roles in signal transduction, development, and malignancy}

Claire Lorenzo and Frank McCormick

Genes Dev. 2020, 34:

Access the most recent version at doi:10.1101/gad.341222.120

$\begin{aligned} & \text { References } \begin{array}{l}\text { This article cites } 89 \text { articles, } 31 \text { of which can be accessed free at: } \\ \text { http://genesdev.cshlp.org/content/34/21-22/1410.full.html\#ref-list-1 }\end{array} \\ & \begin{aligned} \text { Creative } \\ \text { Commons } \\ \text { License }\end{aligned} \begin{array}{l}\text { This article is distributed exclusively by Cold Spring Harbor Laboratory Press for the first } \\ \text { six months after the full-issue publication date (see } \\ \text { http://genesdev.cshlp.org/site/misc/terms.xhtml). After six months, it is available under a } \\ \text { Creative Commons License (Attribution-NonCommercial } 4.0 \text { International), as described } \\ \text { at http://creativecommons.org/licenses/by-nc/4.0/. }\end{array} \\ & \begin{array}{c}\text { Receive free email alerts when new articles cite this article - sign up in the box at the top } \\ \text { right corner of the article or click here. }\end{array} \\ & \text { Service }\end{aligned}$

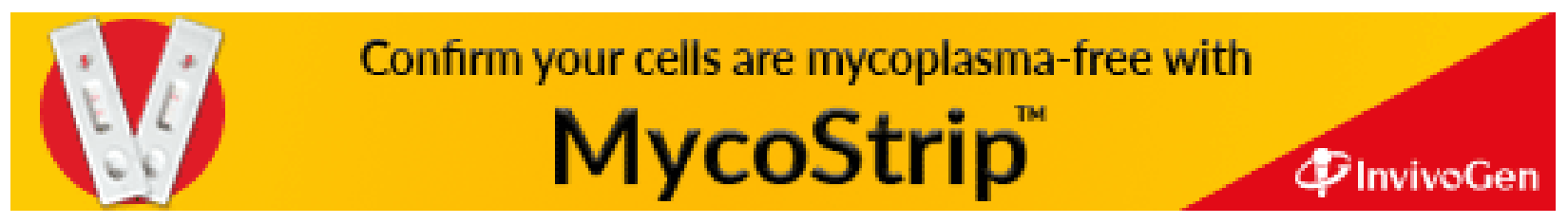

